\title{
Wellbeing Literacy: The Necessary Ingredient in Positive Education
}

\author{
Lindsay G. Oades* and Alexandra L. Johnston \\ Centre for Positive Psychology, University of Melbourne, Australia
}

Submission: April 28, 2017; Published: May 04, 2017

*Corresponding author: Lindsay G. Oades, Associate Professor, Centre for Positive Psychology, University of Melbourne, Australia, Email: lindsay.oades@unimelb.edu.au

\begin{abstract}
Wellbeing can be viewed as a resource for life, resulting in individual skills and community assets. It is not surprising therefore, to see developing research presenting the benefits of integrating learning about wellbeing within educational contexts, with the potential outcome of building sustainable wellbeing literacy. Developing wellbeing knowledge is key to building core wellbeing literacy skills. This in turn can significantly impact employability post education, and therefore, life trajectory. Building and sustaining wellbeing through learning about wellbeing within educational contexts can provide timely, personalised, system-wide opportunities to build capacity in initiating, developing, contributing to and sustaining decision-making toward achieving successful wellbeing and life outcomes.
\end{abstract}

Keywords: Wellbeing; Wellbeing Literacy; Education; Health Promotion; Positive Psychology; Positive Education

\section{Opinion}

Positive psychology is a science of positive subjective experience, positive individual traits, and positive institutions [1]. As an important redirection of inquiry concerning the investigation of human flourishing [2], positive psychology recognizes that good mental, social and physical health consists of wellbeing without pathology [3]. When applied to educational contexts, positive psychology proposes that through positive education we may create a more complete view of the human condition, in seeking to counteract depressive symptoms, increase life satisfaction, and augment learning and creative thinking $[4,5]$. While positive education has been defined as 'education for both traditional skills and happiness' [4], we offer a broader definition, emphasizing the importance of learning environments. Hence, our working definition for positive education is 'the development of educational environments that enable the learner to engage in established curricula in addition to knowledge and skills to develop their own and others' wellbeing'.

The current critique surrounding positive education includes questions of how it is different from established health promotion and social and emotional learning programs [6]. Is positive education simply positive psychology applied in education or does it involve a union with pedagogy $[7,8]$ ? In understanding the debates surrounding positive education, it is useful to understand the broader debates within positive psychology which influence positive education [9].

In defining the 'positive' in positive psychology, Pawelski $[10,11]$ draws useful distinctions between conceptualising the target population, the processes and outcomes of positive psychology. Applying this framework to positive education may lead us to consider school communities as the target population, with an array of processes used within educational contexts (for example, building character strengths), towards realizing wellbeing as the outcome of positive education. Determining how positive education differs from existing approaches can prompt discussions on how positive education is applied to unique school contexts [12] and whether it is more wellbeing focussed than previous mental health approaches. Whilst these debates are conceptually important, from a utilitarian perspective a broader question is how do we improve the wellbeing of the population, in this case through enabling learning about wellbeing?

Discourse within health systems is likely to frame such a discussion within promotion and prevention language, whereas discourse within education systems is likely refer to it as social 
and emotional learning. In adopting Gee's [13] definition of discourse as a social construct, thinking, acting and language use is associated with identifying with a 'social network' [13]. If wellbeing therefore appears to fit well with contemporary health systems discourse, what is the educational discourse around wellbeing, to which positive education contributes? Distinguishing between primary discourse (e.g. family) and secondary discourse (e.g. schools, workplaces) enables us to a more sophisticated understanding of literacy. According to Gee's [13] definition, literacy involves controlling the use of language in contexts outside early experiences, and hence includes school and other educational contexts. Wellbeing literacy is introduced here as the missing ingredient in positive education. The preliminary working definition of wellbeing literacy is "the vocabulary, knowledge and skills that may be intentionally used to maintain or improve the wellbeing of oneself or others" [14].

Key questions to develop a scientific research program on wellbeing literacy, which will aid positive education to establish its proximal outcomes might include:

i. What is wellbeing literacy?

ii. How do we measure wellbeing literacy?

iii. How do laypeople define and linguistically construct wellbeing?

iv. How does wellbeing literacy relate to wellbeing now and over time?

v. How do we increase wellbeing literacy?

vi. What are the systemic implications of wellbeing literacy?

In proposing wellbeing literacy as the missing ingredient for positive education, it is important to distinguish between empirical positive psychological studies demonstrating a short term gain in wellbeing [15], as opposed to building capacity to maintain and reuse wellbeing literacy. This is where wellbeing literacy holds promise for positive education. It is likely to be helpful to shift our thinking from achieving short term gain through an external intervention done to someone; to exploring language mediated co-created actions which may create ongoing sustained wellbeing gains. This relates to the well-known proverb, "You give a man a fish and you feed him for a day. You teach him to fish and will feed him for a lifetime".

\section{Conclusion}

A one-time intervention may increase student wellbeing temporarily. Comprehensive acquisition of, and learning about wellbeing may enable a young person to control their use of language and knowledge of wellbeing, toward improving their own wellbeing or the wellbeing of others. Importantly, achieving wellbeing literacy involves being critical of dominant discourses and societal structures that may impede wellbeing. As language occurs between people and not just within one's head, so too does wellbeing. Where literacy is how we control the use of language, wellbeing literacy is how we control the use of wellbeing language. Language influences thought and action, which in turn may impact life outcomes.

\section{References}

1. Seligman ME, Csikszentmihalyi M (2014) Positive psychology: An introduction. Am Psychol 55(1): 5-14.

2. Rusk RD, Waters LE (2013) Tracing the size, reach, impact, and breadth of positive psychology. The Journal of Positive Psychology 8(3): 207221.

3. Keyes CL (2006) Mental health in adolescence: Is America's youth flourishing? Am J Orthopsychiatry 76(3): 395-402.

4. Seligman ME, Ernst RM, Gillham J, Reivich K, Linkins M (2009) Positive education: Positive psychology and classroom interventions. Oxford review of education 35(3): 293-311.

5. Gable SL, Haidt J (2005) What (and why) is positive psychology? Review of general psychology 9(2): 103.

6. Durlak JA, Weissberg RP, Dymnicki AB, Taylor RD, Schellinger KB (2011) The impact of enhancing students' social and emotional learning: A meta-analysis of school-based universal interventions. Child Dev 82(1): 405-432.

7. Oades LG, Mossman L (2017) The science of wellbeing and positive psychology. Wellbeing, Recovery and Mental health. Cambridge University Press, Cambridge, USA, pp. 7-23.

8. Waters L, Sun J, Rusk R, Cotton A, Arch A (2017) Positive education: visible wellbeing and positive functioning in students. Wellbeing, Recovery and Mental health. Cambridge University Press, Cambridge, USA.

9. Kristjánsson K (2013) Virtues and vices in positive psychology: A philosophical critique. Cambridge University Press, Cambridge, USA.

10. Pawelski JO (2016a) Defining the 'positive' in positive psychology: Part I. A descriptive analysis. The Journal of Positive Psychology 11(4): 339356.

11. Pawelski JO (2016b) Defining the 'positive' in positive psychology: Part II. A normative analysis. The Journal of Positive Psychology 11(4): $357-$ 365 .

12. Kern ML, Park G, Eichstaedt JC, Schwartz HA, Sap M, et al. (2016) Gaining insights from social media language: Methodologies and challenges. Psychol Methods 21(4): 507-525.

13. Gee JP (1998) What is literacy? Negotiating academic literacies: Teaching and learning across languages and cultures. Lawrence Erlbaum, Mahwah, New Jersey, USA.

14. Oades LG, Slade M, Jarden A (2017) Wellbeing and recovery: a possible future. Wellbeing, Recovery and Mental health. Cambridge University Press, Cambridge. USA, pp 324-332.

15. Lyubomirsky S (2007) The how of happiness: A practical guide to getting the life you want. Sphere, UK. 
(C) This work is licensed under Creative (c) DOI: 10.19080/PBSIJ.2017.03.555621

\section{Your next submission with Juniper Publishers} will reach you the below assets

- Quality Editorial service

- Swift Peer Review

- Reprints availability

- E-prints Service

- Manuscript Podcast for convenient understanding

- Global attainment for your research

- Manuscript accessibility in different formats ( Pdf, E-pub, Full Text, Audio)

- Unceasing customer service

Track the below URL for one-step submission https://juniperpublishers.com/online-submission.php 